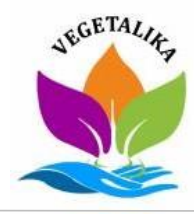

Vegetalika Vol. 10 No. 2, Mei 2021:140-148

Available online at https://jurnal.ugm.ac.id/jbp DOI: https://doi.org/10.22146/veg.54781 p-ISSN: 2302-4054 | e-ISSN: 2622-7452

\title{
Penggunaan Bantuan Penyerbukan Dalam Upaya Peningkatan Hasil Benih Beberapa Aksesi Mentimun (Cucumis sativus L.)
}

\section{The use of Pollination Assistance in an Efforts to Increase Seed Yields of Several Cucumber Accessions (Cucumis sativus L.)}

\author{
Sri Ratna Ningsih Ginting, Taryono*)
}

\author{
Departemen Budidaya Pertanian, Fakultas Pertanian, Universitas Gadjah Mada \\ Jalan Flora No. 1, Bulaksumur, Sleman, Yogyakarta 55281, Indonesia. \\ *) Penulis untuk korespodensi E-mail: tariono60@gmail.com \\ Diajukan: 10 Maret 2020 /Diterima: 31 Maret 2021 /Dipublikasi: 25 Mei 2021
}

\begin{abstract}
The use of seeds to cultivate will determine the yield. Increasing crop yields requires improvements in seed quality, and high cucumber seeds productin can be obtained through artificial pollination. The purpose of this study is to identify the effect of artificial pollination in an effort to increase the yield of cucumber seeds. This research was carried out at the Center for Agrotechnology Innovation (PIAT), Kalitirto, Berbah, Sleman, which is located at an altitude of $\mathbf{1 3 0}$ meters above sea level. The research took place from March to August 2019. This study used a split plot design with 2 factors, namely artificial pollination and cucumber accession. The observational data are take from the results of seed weight per plant, number of seeds per plant, weight of 100 seeds, number of fruits per plant. The data analysis used ANOVA test, with further Scott-Knott test with a confidence level of $5 \%$. All data analysis were performed using $R$ software version 3.5.1. The results showed that the help of Artificial Pollinated of cucumber gave a significant difference in the number of seeds per plant, while the observation of the number of fruits, weight of seeds per plant and weight of 100 seeds did not show any significant difference.
\end{abstract}

Keywords: artificial pollinated; cucumber; open pollinated; seeds

\section{INTISARI}

Penggunaan benih untuk budidaya akan menentukan hasil panen. Untuk meningkatkan hasil panen maka diperlukan adanya peningkatan mutu benih, dan tingginya hasil benih bernas mentimun dapat diperoleh melalui penyerbukan buatan. Tujuan penelitian ini adalah untuk mengetahui pengaruh penyerbukan buatan dalam upaya meningkatkan hasil benih bernas mentimun. Penelitian ini dilaksanakan di Pusat Inovasi Agroteknologi (PIAT), Kalitirto, Berbah, Sleman, yang terletak pada ketinggian 130 mdpl. Penelitian berlangsung pada bulan Maret hingga Agustus 2019. Penelitian ini mengggunakan Rancangan Petak Terbagi (Split Plot) dengan 2 faktor yaitu penyerbukan buatan dan aksesi mentimun. Data pengamatan di ambil dari hasil berat biji per tanaman, jumlah biji per tanaman, berat 100 biji, dan jumlah buah per tanaman. Analisis data menggunakan uji ANOVA, dengan uji lanjut Scott-Knott tingkat kepercayaan $5 \%$. Seluruh analisis data dilakukan menggunakan perangkat lunak $\mathbf{R}$ versi 3.5.1. Hasil penelitian menunjukkan bahwa penyerbukan buatan pada mentimun memberikan perbedaan nyata pada jumlah biji per tanaman, sedangkan untuk pengamatan jumlah buah, berat biji per tanaman ataupun berat 100 biji tidak menunjukkan hasil yang berbeda nyata.

Kata kunci: benih; mentimun; penyerbukan alami; penyerbukan buatan 


\section{PENDAHULUAN}

Mentimun (Cucumis sativus L.) merupakan salah satu jenis sayuran dari keluarga labulabuan (Cucurbitaceae) yang banyak dikonsumsi di Indonesia serta memiliki peluang budidaya yang besar. Dalam sejarah perkembangannya, mentimun berasal dari benua Asia. Beberapa sumber menyebutkan daerah asal mentimun adalah Asia Utara, tetapi sebagian lagi menduga berasal dari Asia Selatan (Rukmana, 1994 cit. Simanullang et al., 2014).

Peluang budidaya mentimun semakin cerah seiring laju pertambahan penduduk, peningkatan pendidikan, dan peningkatan kesadaran gizi masyarakat. Produksi mentimun salah satunya digunakan untuk kosmetik, kesehatan, dan makanan (Kartikasari et al., 2016). Mentimun mempunyai daya adaptasi cukup luas terhadap lingkungan tumbuhnya. Di Indonesia mentimun dapat ditanam di dataran rendah maupun tinggi yaitu lebih kurang 1.000 m dpl (Sumpena, 2001).

Berdasarkan data Badan Pusat Statistik (2008) dalam Birnadi (2017), hasil mentimun Indonesia masih sangat rendah berkisar 3,5-4,8 ton/Ha, padahal potensinya dapat mencapai 20 ton/ha terutama jika menanam varietas hibrida. Selain itu, data BPS dan Direktorat Jendral Hortikultura (2012) dalam Sidauruk et al., (2013) menunjukkan bahwa produktivitas mentimun (ton/ha) di Indonesia bergerak secara fluktuatif. Produksi mentimun (ton/thn) berturut-turut pada tahun 2007 sampai 2011 adalah 581.205, 540.122, 583.139, 547.141, 527.184, sedangkan, berdasarkan data dari Direktorat Jenderal Hortikultura Departemen Pertanian, produksi mentimun di Indonesia selama 2007 sampai 2011 memperlihatkan kecenderungan yang fluktuatif. Panen seluas 55.809 ha per tahun dan produksi 544.983 ton per tahun (Zulkarnain, 2013 cit. Wiguna, 2014).

Tanaman cucurbit memiliki berbagai jenis ekspresi kelamin dan sebagian besar budidaya komersial varietas tanaman ini berumah satu (monoecious), andromonoecious, atau gynoecious. Tipe monoecious menghasilkan bunga staminate (jantan) atau pistillate (betina) dalam bunga terpisah pada tanaman yang sama. Tipe Andromonoecious memiliki bunga staminate dan hermaprodit (sempurna) dalam satu tanaman, sedangkan tipe gynoecious hanya menghasilkan bunga betina saja. (Free, 1993; Delaplane dan Mayer, 2000 cit. Bomfim et al., 2016).

Dalam satu tanaman mentimun dapat memiliki bunga jantan, bunga betina, atau bunga hermaprodit. Mentimun umumnya lebih banyak menghasilkan bunga jantan dibandingkan bunga betina, namun dengan perlakuan tertentu, persentase bunga betina dapat ditingkatkan. Dalam budidaya mentimun terdapat kendala diantaranya jumlah bunga jantan lebih sedikit daripada jumlah bunga betina yang dihasilkan. Jumlah bunga betina yang lebih banyak dibutuhkan untuk memberikan hasil yang tinggi. Hasil mentimun dipengaruhi oleh kondisi lingkungan dan fotoperiodisme yang mempengaruhi dalam pembentukan bunga. Selain itu, rendahnya rasio antara bunga betina dan bunga jantan juga merupakan penyebab rendahnya hasil buah mentimun (Kartikasari et al., 2016). Tanaman yang terdapat banyak jumlah bunga betina baik digunakan untuk peningkatan hasil 
sedangkan tanaman yang jumlah bunga jantannya lebih banyak digunakan sebagai pejantan dalam kegiatan hibridisasi (Kusandriani et al., 2012 cit. Wiguna 2014), sehingga diperlukan jumlah bunga betina yang lebih banyak dibandingkan bunga jantan untuk meningkatkan jumlah buah. Jumlah buah yang sedikit akan mempengaruhi jumlah benih yang dihasilkan.

Tanaman mentimun termasuk dalam tanaman dengan sistem penyerbukan xenogami (outcrossing), namun bisa juga menerima serbuk sari mereka sendiri untuk set buah (kompatibel sendiri), yang memiliki campuran tipe tanaman (Bomfim et al., 2016). Dan karena rendahnya jumlah bunga staminate yang biasanya dihasilkan pada hibrida gynoecious (seperti mentimun) umumnya membutuhkan sumber tambahan serbuk sari untuk menghasilkan buah (Free, 1993; Delaplane dan Mayer, 2000 cit. Bomfim et al., 2016). Oleh karena itu, dibutuhkan suatu upaya untuk meningkatkan hasil benih bernas mentimun, salah satunya dengan melakukan penyerbukan buatan. Pada penelitian dilakukan upaya penyerbukan buatan sebagai upaya peningkatan hasil benih mentimun.

\section{BAHAN DAN METODE}

Penelitian ini berlangsung pada bulan Maret hingga Agustus 2019. Penelitian ini menggunakan Rancangan Split Plot yang terdiri atas dua faktor. Faktor pertama yaitu 27 aksesi mentimun sebagai bahan tanam dan faktor kedua yaitu perlakuan bantuan penyerbukan. Pengacakan dilakukan pada setiap aksesi.

Setiap aksesi terdiri dari 10 tanaman yang ditanam secara baris pada lahan yang terpisah. Lahan kontrol ditanami 5 tanaman per aksesi dan lahan perlakuan juga 5 tanaman per aksesi. Pengamatan dimulai pada saat tanaman mulai berbunga. Pengamatan dilakukan pada semua tanaman kecuali tanaman tepi. Pengamatan dilakukan setelah panen meliputi berat biji per tanaman, jumlah biji per tanaman, berat 100 biji, jumlah buah per tanaman.

Analisis data dilakukan menggunakan uji ANOVA, apabila hasil uji ANOVA menunjukkan terdapat interaksi antara kedua faktor, dilakukan uji lanjut Scott-Knott tingkat kepercayaan 5\%. Seluruh analisis data dilakukan menggunakan perangkat lunak $R$ versi 3.5.1.

\section{HASIL DAN PEMBAHASAN}

Setiap tanaman mengalami pertum-buhan dan perkembangan. Pertumbuhan adalah peristiwa bertambahnya ukuran tanaman, yang dapat diukur dari bertambah besar dan tingginya organ tumbuhan, sedangkan perkembangan tanaman dilihat dari perubahan pada bentuk organ batang, akar dan daun, munculnya bunga serta terbentuknya buah (Sitompul dan Guritno, 1995). Dari hasil pertumbuhan tanaman tersebut terdapat beberapa ciri kuantitatif yang dapat diukur dalam proses pertum-buhan tanaman. Adapun ciri kuantitatif yang diamati yaitu jumlah buah per tanaman, berat biji per tanaman, jumlah biji per tanaman, berat 100 biji.

\section{Jumlah Buah dan Jumlah Biji Per Tanaman}

Mentimun memiliki tipe pertumbuhan indeterminate atau tipe pertumbuhan terus menerus karena tanaman memiliki kemampuan pertumbuhan yang terus menerus, sehingga ketika tanaman terus tumbuh dan berkembang untuk menghasilkan bunga maka besar kemungkinan terjadinya penyerbukan. Dari tingginya tingkat keberhasilan penyerbukan, 
maka akan menghasilkan jumlah buah yang tinggi pula. Menurut Mahdi (2013) cit. Wiguna (2014) bahwa tanaman yang memiliki tipe pertumbuhan indeterminate akan tumbuh lebih baik apabila dibandingkan dengan tipe determinate karena dengan pertumbuhan yang terus menerus akan memiliki potensi menghasilkan buah lebih banyak.

Perbedaan nyata terjadi antara hasil jumlah biji dari penyerbukan buatan (Artificial Pollinated) dengan penyerbukan alami (Open Pollinated) pada aksesi CB-T41, CB-T42, CB-T48, CB-T50, CB-T53, CB-T54, CB-T55, CB-T56, CB-T57, CBT60, dan CB-T61 (Tabel 2). Hasil jumlah biji tertinggi dari penyerbukan buatan dihasilkan oleh aksesi CB-T55 dengan rerata 5,245 biji, dan biji terendah dari aksesi CB-T48 dengan rerata 2,685 biji. Dari hasil penyerbukan alami, jumlah biji tertinggi dihasilkan oleh aksesi CB-T99 dengan rerata 5,436 biji dan terendah dihasilkan aksesi CB-T87 dengan rerata 2,236 biji. Hasil jumlah biji mentimun yang berbeda-beda dipengaruhi oleh hasil penyerbukan yang telah terjadi. Alia dan Wilia, (2011) dalam Rahmi et al., (2015) melaporkan bahwa besarnya persentase polong atau biji yang terbentuk dipengaruhi oleh beberapa faktor, diantaranya biologi bunga, ketersediaan serbuk sari, curah hujan, suhu, kelembaban, faktor pemeliharaan dan faktor keterampilan pemulia.

Tabel 1. menunjukkan perbandingan jumlah buah pada penyerbukan buatan dan penyerbukan alami. Diketahui bahwa aksesi hasil penyerbukan buatan dengan rerata jumlah buah tertinggi dihasilkan oleh CB-T84 dengan rerata 1,282, sedangkan hasil buah terendah dihasilkan oleh CB-T52 dengan rerata 0,841 buah. Hasil buah penyerbukan alami tertinggi dihasilkan oleh aksesi CB-T64 dan CB-T 99 dengan rerata 1,25 buah, dan hasil terendah dihasilkan oleh aksesi CB-T57 dengan rerata 0,92 , tetapi berdasarkan analisis uji lanjut Scott Knott menunjukkan tidak berbeda nyata antara jumlah buah yang dihasilkan pada penyerbukan alami (Open Pollinated) dan penyerbukan buatan (Artificial Pollinated).

Rahmi et al., (2015) menyatakan bahwa banyak faktor yang dapat mempengaruhi tingkat keberhasilan penyerbukan, diantaranya kondisi serbuk sari yang digunakan dan tingkat kompabilitas. Penyerbukan yang menghasilkan buah disebut kompatibel, sedangkan yang tidak dapat membentuk buah disebut inkompabel. Kemampuan serbuk sari dalam membuahi bakal buah pada sel kelamin betina yang terletak pada bunga sangat berperan penting dalam proses penyerbukan yang menghasilkan buah. Selain itu, menurut Ekeke et al. (2018) dalam penelitiannya keberhasilan terbentuknya buah pada bunga yang diserbuki berpeluang besar apabila dilakukan penyerbukan antara pukul 05.00 hingga 16.00 , akan tetapi peluang keberhasilan lebih kecil/tidak ada buah yang terbentuk pada bunga yang diserbuki 24 jam. setelah bunga mekar. 
Tabel 1. Jumlah buah dan jumlah biji per tanaman pada 27 aksesi mentimun

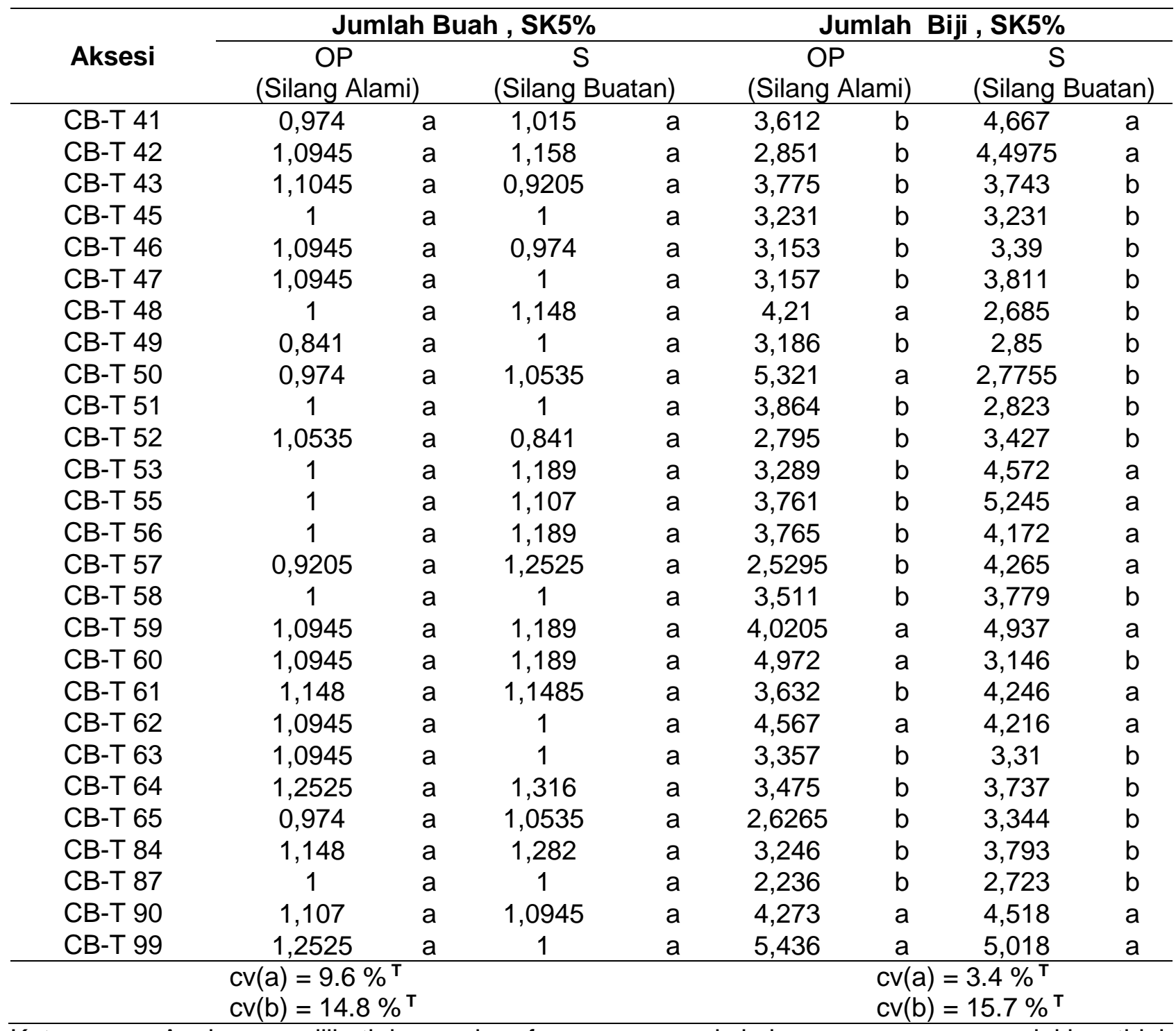

Keterangan: Angka yang diikuti dengan huruf yang sama pada kolom yang sama menunjukkan tidak berbeda nyata berdasarkan uji Scott Knott pada taraf nyata $5 \%$. Tanda ${ }^{\top}$ yang terdapat pada nilai CV menunjukkan nilai hasil transformasi. CV(a): perlakuan; $\mathrm{CV}(\mathrm{b})$ : aksesi

Pembentukan biji mentimun dipengaruhi pula oleh jumlah buah dan ukuran buah yang terbentuk pada masing-masing tanaman. Semakin banyak buah yang terbentuk dari perlakuan penyerbukan yang diberikan akan menghasilkan biji yang lebih banyak, begitu sebaliknya. Hasil benih secara kuantitatif dan kualitatif dipengaruhi oleh beberapa faktor seperti nutrisi tanaman induk, kondisi iklim area produksi benih, jumlah buah per tanaman, dan jumlah biji per buah (Cebeci dan Padem, 2014 cit. Golabadi et al., 2019). Golabadi et al., (2019) menyebutkan bahwa perbandingan antara waktu penyerbukan dengan interaksi umur bunga jantan menunjukkan interaksi tidak hanya pada total biji kering dan bobot biji penuh yang dihasilkan, tetapi juga pada persentase hasil benih dalam buah lebih tinggi untuk bunga jantan muda daripada bunga jantan tua, dan disebutkan pula bahwa pada pukul 12.00-13.45 siang, suhu dan kelembaban rumah kaca sangat menguntungkan untuk dilakukan penyerbukan, 
karena penerimaan pada stigma/putik maksimum terhadap butiran serbuk sari, sehingga jika bunga betina disilangkan dengan bunga jantan muda pada waktu tersebut akan memperoleh hasil yang mengarah ke lebih banyak hasil benih (berat dan jumlah).

\section{Berat Biji dan Berat 100 Biji Per Tanaman}

Kumar et al. (2008) dalam Golabadi et al., (2019) melaporkan bahwa beberapa faktor dapat mempengaruhi hasil buah, pembentukan buah, hasil biji, dan mutu seperti berat biji per buah, jumlah biji per buah, berat 1000 biji, berat biji per tanaman, perkecambahan, panjang akar, dan panjang tunas tomat. Dari penjelasan tersebut diperoleh data hasil penelitian terkait berat biji dan berat 100 per tanaman dan diperoleh hasil yang beragam. Data yang ditunjukkan pada Tabel 2 merupakan data perbandingan berat biji per tanaman hasil dari penyerbukan buatan (Artificial Pollinated) dengan penyerbukan alami (Open Pollinated) pada 27 aksesi mentimun. Berat biji per tanaman ini termasuk didalamnya benih sehat, benih rusak, serta benih abnormal. Berat biji tertinggi pada penyerbukan buatan dihasilkan oleh nomor aksesi CB-T64 dengan hasil 1,314 dan berat biji terendah pada aksesi CB-T84 dan CBT90 dengan hasil 0,5 sedangkan pada penyerbukan alami dihasilkan berat biji tertinggi pada aksesi CB-T45 dengan hasil 1,333 dan berat biji terendah pada aksesi CB-T57 dengan hasil 0,96 . Dari hasil analisis pada Tabel 2 menunjukkan tidak terdapat perbedaan nyata pada berat biji per tanaman hasil dari penyerbukan buatan (Artificial Pollinated) dengan penyerbukan alami (Open Pollinated).
Adanya perbedaan berat biji yang dihasilkan dapat dipengaruhi oleh jumlah buah dari hasil penyerbukan yang telah terbentuk. Faktor lain seperti pada proses polinasi atau penyerbukan buatan, jumlah polen yang digunakan sangat berpengaruh terhadap keberhasilan pembentukan buah mentimun dari pada proses tersebut. Serta kondisi kematangan yang sama dari polen dan stigma akan mampu meningkatkan keberhasilan penyerbukan menjadi semakin tinggi (Wijaya, et al., 2015). Viabilitas serbuk sari yang digunakan juga akan mempengaruhi viabilitas benih yang dihasilkan (Widiastuti dan Palupi, 2008 cit. Wijaya, et al., 2015). Zaman (2006) dalam Harliani, et al., (2014) menyatakan bahwa viabilitas serbuk sari tanaman mentimun dari bunga segar berkisar antara 96,2-97,8\%, pada melon $88,2-97,7 \%$ dan pada semangka 94,7-95\%.

Menurut Schmidt (2000) dalam Wijaya, et al., (2015), faktor yang sering dijumpai dalam kegagalan bunga untuk menghasil-kan benih adalah kegagalan dalam proses penyerbukan. Dalam produksi benih mentimun, keberhasilan penyerbukan erat kaitannya dengan tingkat kematangan dari bunga jantan dan bunga betina tanaman mentimun. Sehingga, diperlukan waktu yang cocok dalam proses penyerbukan untuk melihat reseptifitas stigma dan viabilitas polen berada pada tingkat kematangan yang sama. Perbandingan jumlah bunga jantan dengan bunga betina yang digunakan dalam proses polinasi juga sangat penting untuk menghasilkan jumlah biji dengan kualitas yang baik. 
Tabel 2. Berat Biji Per Tanaman dan Berat 100 pada 27 Aksesi Mentimun

\begin{tabular}{|c|c|c|c|c|c|c|c|c|}
\hline \multirow{3}{*}{$\begin{array}{l}\text { Aksesi } \\
\text { CB-T } 41\end{array}$} & \multicolumn{4}{|c|}{ Berat Biji , SK5\% } & \multicolumn{4}{|c|}{ Berat 100 Biji , SK5\% } \\
\hline & \multicolumn{2}{|c|}{$\begin{array}{c}\text { OP } \\
\text { (Silang Alami) }\end{array}$} & \multicolumn{2}{|c|}{$\begin{array}{c}\text { S } \\
\text { (Silang Buatan) }\end{array}$} & \multicolumn{2}{|c|}{$\begin{array}{c}\text { OP } \\
\text { (Silang Alami) }\end{array}$} & \multicolumn{2}{|c|}{$\begin{array}{c}\text { S } \\
\text { (Silang Buatan) }\end{array}$} \\
\hline & 1,125 & $a$ & 1,1635 & a & 1,1295 & $\mathrm{a}$ & 1,1015 & $\mathrm{a}$ \\
\hline CB-T 42 & 1,122 & $\mathrm{a}$ & 1,1575 & a & 1,158 & $\mathrm{a}$ & 1,1425 & a \\
\hline CB-T 43 & 1,192 & $\mathrm{a}$ & 1,225 & a & 1,107 & $\mathrm{a}$ & 1,099 & a \\
\hline CB-T 45 & 1,333 & $\mathrm{a}$ & 1,245 & a & 1,138 & $\mathrm{a}$ & 1,108 & a \\
\hline CB-T 46 & 1,192 & $\mathrm{a}$ & 1,154 & a & 1,195 & $\mathrm{a}$ & 1,075 & a \\
\hline CB-T 47 & 1,1455 & $\mathrm{a}$ & 1,1325 & a & 1,1265 & $\mathrm{a}$ & 1,093 & a \\
\hline CB-T 48 & 1,099 & a & 1,026 & a & 1,011 & a & 1,1375 & a \\
\hline СВ-Т 49 & 1,0855 & a & 1,0375 & a & 1,098 & $a$ & 1,158 & a \\
\hline CB-T 50 & 1,13 & a & 1,1165 & a & 1,05 & $\mathrm{a}$ & 1,2175 & a \\
\hline CB-T 51 & 1,1815 & a & 1,199 & a & 1 & $\mathrm{a}$ & 1,202 & a \\
\hline CB-T 52 & 1,069 & a & 1,304 & a & 1,127 & $\mathrm{a}$ & 1,296 & a \\
\hline СВ-Т 53 & 1,118 & a & 1,248 & a & 1,0945 & $\mathrm{a}$ & 1,024 & a \\
\hline СВ-Т 55 & 1,081 & a & 1,088 & a & 0,922 & $\mathrm{a}$ & 1,098 & a \\
\hline СВ-Т 56 & 1,122 & a & 1,2045 & a & 1,004 & $\mathrm{a}$ & 1,187 & a \\
\hline CB-T 57 & 0,96 & a & 1,2065 & a & 1,215 & $a$ & 1,13 & a \\
\hline CB-T 58 & 1,15 & a & 1,1975 & a & 1,0985 & $\mathrm{a}$ & 1,108 & $\mathrm{a}$ \\
\hline CB-T 59 & 1,154 & a & 1,22 & a & 1,0875 & $\mathrm{a}$ & 1,083 & $\mathrm{a}$ \\
\hline CB-T 60 & 1,119 & a & 1,1105 & a & 1,097 & $\mathrm{a}$ & 1,1 & $\mathrm{a}$ \\
\hline CB-T 61 & 1,156 & a & 1,2645 & a & 1,142 & $\mathrm{a}$ & 1,115 & $\mathrm{a}$ \\
\hline CB-T 62 & 1,1055 & $\mathrm{a}$ & 1,1405 & a & 1,092 & $\mathrm{a}$ & 1,157 & $\mathrm{a}$ \\
\hline CB-T 63 & 1,1665 & $\mathrm{a}$ & 1,246 & a & 1,0905 & $\mathrm{a}$ & 1,038 & $\mathrm{a}$ \\
\hline CB-T 64 & 1,268 & $\mathrm{a}$ & 1,314 & a & 1,1515 & $\mathrm{a}$ & 1,278 & $\mathrm{a}$ \\
\hline CB-T 65 & 1,095 & $\mathrm{a}$ & 1,25 & a & 1,111 & $a$ & 1,229 & $\mathrm{a}$ \\
\hline CB-T 84 & 1,11 & $\mathrm{a}$ & 0,5 & a & 1,0515 & $a$ & 1,112 & $a$ \\
\hline CB-T 87 & 0,997 & a & 1,181 & a & 1,186 & $a$ & 0,5 & $a$ \\
\hline СB-T 90 & 1,148 & a & 0,5 & a & 1,072 & $a$ & 1,0985 & $a$ \\
\hline \multirow[t]{2}{*}{ CB-T 99} & 1,272 & $a$ & 1,28 & a & 1,1275 & a & 1,092 & $a$ \\
\hline & \multicolumn{4}{|c|}{$\begin{array}{l}\operatorname{cv}(a)=28,6 \%^{\top} \\
\operatorname{cv}(b)=6,6 \%^{\top}\end{array}$} & \multicolumn{4}{|c|}{$\begin{array}{l}\mathrm{cv}(\mathrm{a})=22,5 \%^{\top} \\
\mathrm{cv}(\mathrm{b})=12,3 \%^{\top}\end{array}$} \\
\hline
\end{tabular}

Keterangan: Data merupakan hasil dari analisis. Angka yang diikuti dengan huruf yang sama pada kolom yang sama menunjukkan tidak berbeda nyata berdasarkan uji Scott Knott pada taraf nyata $5 \%$. Tanda ${ }^{\top}$ yang terdapat pada nilai CV menunjukkan nilai hasil transformasi. CV(a) :perlakuan; CV(b) : aksesi

Ahmed et al. (2004) dalam Wijaya, et al., (2015) menyatakan bahwa rasio antara bunga jantan dan bunga betina yang terdapat dalam satu tanaman akan mempengaruhi jumlah buah pertanaman pada berbagai kondisi lingkungan. Cebeci dan Padem (2014) dalam Golabadi et al., (2019) melaporkan bahwa jumlah 6-8 buah per tanaman adalah jumlah yang paling baik karena memunculkan hasil biji yang lebih tinggi dengan penurunan mutu benih yang paling sedikit.
Pada Tabel 2 dapat diketahui bahwa hasil penyerbukan buatan memperoleh berat 100 biji tertinggi di aksesi CB-T52 dengan rerata 1,296 g dan terendah pada aksesi CB-T87 dengan rerata $0,5 \mathrm{~g}$ sedangkan hasil tertinggi pada penyerbukan alami dihasilkan aksesi CB-T46 dengan rerata $1,195 \mathrm{~g}$ dan hasil terendah pada aksesi CB-T55 dengan rerata 0,922 g. Namun, hasil dari tabel 2 tersebut juga menunjukkan tidak adanya perbedaan nyata antar perlakuan dengan aksesi mentimun yang digunakan. 
Menurut Pulungan et al., (2014) dalam Rahmi et al., (2015) bobot 100 butir benih dipengaruhi oleh ukuran atau tipe benih. Hasil peneltian ini tidak sesuai dengan teori, karena dari hasil terlihat bahwa jumlah buah dan berat 100 benih yang diperoleh tidak memberikan pengaruh yang berbeda nyata antar perlakuan pada penyerbukan buatan dan kontrolnya. Ukuran dan bentuk dari biji mempengaruhi hasil berat. Adapun beberapa bentuk biji kering mentimun dapat dikelompokkan dalam elips, elips pendek, elips panjang, dan pisau bedah. Faktor genetik dan lingkungan juga dapat menyebabkan jumlah benih bernas berbeda (Sa'diyah et al., 2013 cit. Rahmi et al., 2015).

\section{KESIMPULAN}

Dari hasil penelitian yang dilakukan diperoleh bahwa bantuan penyerbukan pada mentimun memberikan perbedaan nyata pada jumlah biji pertanaman, sedangkan untuk pengamatan lain seprti jumlah buah per tanaman, berat biji per tanaman atau berat 100 biji tidak menunjukkan adanya hasil yang berbeda nyata. Sehingga perlu dilakukan penelitian lebih lanjut mengenai waktu yang tepat dalam melakukan penyerbukan untuk mengetahui pengaruh waktu penyerbukan terhadap keberhasilan upaya penyerbukan yang dilakukan, sehingga akan dapat diketahui waktu yang tepat untuk mendapatkan hasil benih mentimun yang terbaik ketika dilakukan bantuan persilangan.

\section{UCAPAN TERIMA KASIH}

Terima kasih kepada Dr. Ir. Taryono, M.Sc. atas saran dalam penulisan penelitian ini serta kepada Pusat Inovasi Agroteknologi UGM atas izin dalam penggunaan lahan untuk pelaksanaan penelitian.

\section{DAFTAR PUSTAKA}

Birnadi, Suryaman. 2017. Respons Mentimun Jepang (Cucumis sativus L.) Var. Roberto Terhadap Perendaman Benih Dengan Giberelin $\left(\mathrm{GA}_{3}\right)$ dan Bahan Organik Hasil Fermentasi (Bohasi). <https://studylibid.com/doc/969728/edisi -juni-2017-volume-x-no.-2>. Edisi Juni 10 (2):77-90.

Bomfim, I.G.A., Breno Magalhães Freitas, Fernando Antonio Souza de Aragão, and Stuart Alan Walters. 2016. Pollination in Cucurbit Crop. Handbook of Cucurbits: Growth, Cultural Practices, and Physiology (pp.181-200). CRC Press. Florida

Ekeke, C., Ogazie, C. A. and Agbagwa, I.O.. 2018. Breeding biology and effect of pollinators on the fruit characteristics of cucumber (Cucumis sativus L.), Cucurbitaceae. Nigerian Journal of Botany. 31(2):325-344.

Golabadi M., Sezai Ercisli, Forough Ahmadi. 2019. Environmental and physiological effects on cross-ability and seed production of greenhouse cucumber. Journal of Seed Science. 41(2):134-143.

Harliani, E. N., Endah Retno Palupi, dan Dudin Supti Wahyudin. 2014. Potensi penyimpanan serbuk sari dalam produksi benih hibrida mentimun (Cucumis 
sativus L.) varietas KE014. Jurnal Hortikultura Indonesia. 5(2):104-117.

Kartikasari, Oktavian, Nurul Aini dan Koesriharti. 2016. Respon tiga varietas mentimun (Cucumis sativus L.) terhadap aplikasi zat pengatur tumbuh giberelin $\left(G A_{3}\right)$. Jurnal Produksi Tanaman. 4(6):425-430.

Rahmi, Yusvita Maulidia, Sri Lestari Purnamaningsih dan Sumeru Ashari. 2015. Tingkat viabilitas benih mentimun (Cucumis sativus L.) hasil penyerbukan. Jurnal Produksi Tanaman. 3(1):50-55.

Sidauruk, Cici Octavia, Jasmani Ginting, Justin Napitupulu. 2013. Pengaruh konsentrasi dan frekuensi aplikasi ethepon terhadap pertumbuhan dan produksi mentimun (Cucumis sativus L.). Jurnal Online Agroekoteknologi. 2(1):54-63.

Simanullang, Vernando, Mbue Kata Bangun, Hot Setiado. 2014. Respon pertumbuhan beberapa varietas timun (Cucumis sativus L.) terhadap pemberian pupuk organik. Jurnal Online Agroekoteknologi. 2(2):680-890.

Sitompul, SM dan Guritno B. 1995. Analisis Pertumbuhan Tanaman. Gadjah Mada University Press, Yogyakarta.

Sumpena, U. 2001. Budidaya Mentimun Intensif. Penebar Swadaya, Jakarta.

Wiguna, G. 2014. Keragaan fenotifik beberapa genotipe mentimun (Cucumis sativus L.). Mediagro. 10 (2):45-56.

Wijaya, S. A., Nur Basuki, dan Sri Lestari Purnamaningsih. 2015. Pengaruh waktu penyerbukan dan proporsi bunga betina dengan bunga jantan terhadap hasil dan kualitas benih mentimun (Cucumis sativus L.) hibrida. Jurnal Produksi Tanaman. 3(8):615-622. 